\title{
Inclusive Education In Indonesia From The Perspective Of Widyaiswara In Centre For Development And Empowerment Of Teachers And Education Personnel Of Kindergartens And Special Education
}

\author{
${ }^{1 * E d i y a n t o,},{ }^{2}$ Iva Nandya Atika, ${ }^{3}$ Norimune Kawai, ${ }^{4}$ and Edy Prabowo \\ 1Student of Graduate School for International Development and Cooperation (1-5-1 Kagamiyama, Higashi-Hiroshima City, Hiroshima, 739-8529, Japan) \\ 2 Professor of Department of Special Needs Education, Graduate School of Education, Hiroshima University, Japan \\ 3WidyaIswara of Centre for Development and Empowerment of Teachers and Education Personnel of Kindergartens and Special Education
}

\begin{abstract}
Abstrak: Since 2009, Indonesia has an excellent commitment and effort in the field of inclusive education. The government provides equal opportunities in education. Through Centre for Development and Empowerment of Teachers and Education Personnel of Kindergartens and Special Education (PPPPTK TK \& PLB), the government provides training and services to teachers in the field of inclusive education and special education. The teacher trainers in PPPPTK TK \& PLB are called Widyalswara. The purpose of this study is to know the implementation of inclusive education in Indonesia from the perspective of Widyalswara of PPPPTK TK \& PLB. The research used qualitative method. This research was conducted on March 2nd, 2017 in PPPPTK TK \& PLB located in Bandung, Indonesia. Data were collected using a questionnaire in the interview related to perceptions about special and inclusive education. The interview process used the instrument in interview form to experts that called WidyaIswara with closed-ended questions. A total of 3 Expert in Inclusive Education in PPPPTK participated in this activity. From the findings and discussion of the research, explained about Widyalswara's perception about: 1) Awareness of students to go to school, 2) Grouping of students with special needs in special and general schools, 3) Distribution of Special Schools in Indonesia, 4) Supporting educational facilities and infrastructure in special and inclusive schools, 5) Teacher in special and inclusive Schools, 6) Learning Activities, 7) Children with special needs after graduation at a level of education, and 8) Government efforts.
\end{abstract}

Keywords: Inclusive Education, Special Education, PPPPTK TK \& PLB.

\section{Introduction}

Great efforts are being made to get all primary age children into school and to complete primary education as part of the Millennium Development Goals (MDGs) and Education for All (EFA) (Rieser, 2012).

The Government of Indonesia made political commitments at the World Education Forum (2000) for achieving

* Corresponding author: Sugiono

Sugiono_ub@ub.ac.id

Published online at http://IJDS.ub.ac.id/

Copyright $@$ 2014PSLD UB Publishing. All Rights Reserved
Basic Education for All. Guided by the mission of education and educational strategies, the Republic of Indonesia enacted a new Law on National Education System (Act N0. 20/ 2003). The Law has its roots in the 1945 Constitution of Indonesia, Article 31, Section (1), which states that each and every citizen have the fundamental right to education. The key targets include expansion and equity, the improvement of quality and relevance, and the implementation of autonomy in higher education. Its main thrust is to make 
education relevant to societal needs; to further the development of communitybased education; and to enhance participation by the community in supporting basic education (Hadis, 2005).

As stated in the 1945 Republic of Indonesia's Constitution that every citizen has the same right to obtain education, this indicates that all people have equal opportunity to get education without exception, including children with special needs. The citizens with disabilities also have the right to education which designed according to their limitations. One of the efforts to facilitate children with special needs is realized with the establishment of various types of special education for children with special needs, such as Special Schools start from Elementary school until Senior High School, but unfortunately it still exclude the children with special needs from the their real social life. In the development of education, nowadays in Indonesia has been developing an inclusive education system to eliminate discrimination between children with special needs and the society.

Inclusive education is not another name of education, inclusive education using different approach in identifying and trying to solve the difficulties that arise in the school (Poernomo, 2016). Based on UNESCO (2009) inclusive education in Indonesia is a priority policy from the Ministry of Education in order to expand educational services for all children with special needs by using a flexible curriculum with due regard to local wisdom and the learning process using information technology. Indonesia regulates inclusive education in Permendiknas No 70, 2009. Permendiknas No. 70, 2009 on Inclusive Education "Inclusive education is a system of education that provides opportunities for all learners who have abnormalities and have the potential of intelligence and/or special talents to follow education or learning in an educational environment together with learners in general".

Indonesia government conducts compulsory education to all school-aged children, including disabled children. However, the participation rate of children with special needs in Indonesia still low. Based on Hamid Muhammad as a directorate general of primary secondary education the rate of participation children with special needs is still only 10-11 percent of the total 1.6 million children with special needs in Indonesia (Meirina, 2015). In other hand, there are still many factors that children with special needs are expelled from school even in society. Lack of learning support facilities for children with special needs, limited the number of teachers, and difficult schools access especially in remote areas are the example of the problem which is faced in Indonesia.

To face that case, as a form of cooperation, among others, it is urging to open a study/majors program of special education (PLB) and provides inclusive educational courses to prepare educator for children with special needs. This program targets prospective pupil teachers and teachers of public schools through training. In addition to that the supply of lecturers in inclusive schools also received special attention from the Ministry of Education, by involving non-Teacher Training College, Teacher Training College (LPTK), Universities and Center for Empowerment and Training for Teacher and Education Personal (PPPPTK) (especially Center for Empowerment and Training for Teacher and Education Personal for Teacher in Kindergarten and Special Needs Education (PPPPTK TK \& PLB) in Bandung, Indonesia (UNESCO International Bureau of Education in Jakarta, 2009). The Center for the Development and Empowerment of Educators and Education Personnel

Ediyanto, Atika, Iva nadya, Kawai, Norimune,, Prabowo, Edy. Inclusive Education In Indonesia From The Perspective Of Widyaiswara In Centre For Development And Empowerment Of Teachers And Education Personnel Of Kindergartens And Special Education Indonesian Journal of Disability Studies (IJDS). 2017: Vol. 04 (02): 104-116. 
(PPPPTK) is the center of trainers of educators and education personnel under the Ministry of Education and Culture. Inclusion education is covered by PPPPTK Kindergarten and Special Education. PPPPTK Kindergarten and Special Education have program targets prospective pupil teachers and teachers of public schools through training. The experts in inclusive education in PPPPTK called "Widyaiswara" that trained teachers from various areas in Indonesia to organize special schools and inclusive schools in their region.

The successful implementation of inclusive education is influenced by many factors including cultural, political, human resources (Kwon, 2005). The implementation of inclusive education can be evaluated by an index called index for inclusion (Ainscow, 2000). This inclusion index is built from three dimensions, namely (1) the cultural dimension (creating inclusive cultures), (2) the producing inclusive policies, and (3) the evolving inclusive practices. Each dimension is divided into two sections: Cultural dimension consists of a building community section and a section on establishing inclusive values. The policy dimension consists of developing the setting for all sections and sections implementing support for diversity (organizing support for diversity). While the practice dimension consists of learning and play section (orchestrating play and learning) and the mobilization resources section (mobilizing resources).

The main principles of education still require assessment as the basis for implementation. The main basis of inclusive education is "ABK and accuracy of learning services" (Sunardi, 1995). In connection with this it is not easy to change the inclusive education system that is already inherent, especially in the level of praxis. Ideally this should be known by looking at the perspective of experts or

teacher trainers in the field of inclusive education. This perspective will provide an overview of inclusive education in Indonesia.

There are the awareness of parent about the importance of inclusive education, ideal condition of inclusive school, competence improvement of teachers in classroom, and developing of the networking with related institution become the main goal that researchers want to do in this study to know the implementation of inclusive education in Indonesia based on experienced experts in inclusion or inclusive education.

A purpose of this research is to know the implementation of inclusive education from the perspective of Widyaiswara of PPPPTK Kindergarten and Special Education on aspects: 1) Student awareness to go to school; 2) Ideal condition of teacher, learning activities, and facilities in inclusive school; and 3) Other finding from Widyaiswara information.

\section{Method}

The research used qualitative method. Based on John W. Creswell (2014) qualitative methods rely on text and image data, have unique steps in data analysis, and draw on diverse designs. Besides that qualitative method also using specific protocols for recording data, analyzing the information through multiple steps of analysis. This research was conducted on March 2nd, 2017 in PPPPTK TK and PLB located in Bandung, Indonesia. Data were collected using a questionnaire in the interview related to perceptions about special and inclusive education. Demographic questions included information of Name, position, last education, and experience in the field of inclusive education. Questions in interview included aspects: 1) awareness to go to Perspective Of Widyaiswara In Centre For Development And Empowerment Of Teachers And Education Personnel Of Kindergartens And Special Education Indonesian Journal of Disability Studies (IJDS). 2017: Vol. 04 (02): 104-116. 
school, 2) grouping of students with special needs in class, 3) school deployment, 4) facilities and infrastructure, 5) teacher, 6) learning activities, 7) after graduating, and 8) governments efforts.

The interview process used the instrument in interview form to experts with closed-ended questions. A total of 3 Expert in Inclusive Education in PPPPTK participated in this activity. Experts answer all questions about inclusive education. All questions answered in according to the circumstances and expert knowledge. The selected expert have experience in inclusive education for at least 3 years and teacher trainer of inclusive education in Indonesia. The expert who is the speaker is called Widyaiswara. Widyaiswara abbreviated as WI. WI1 means the first speaker, WI2 means the second speaker, and WI3 means the third speaker. Data analysis in this research is done by following step

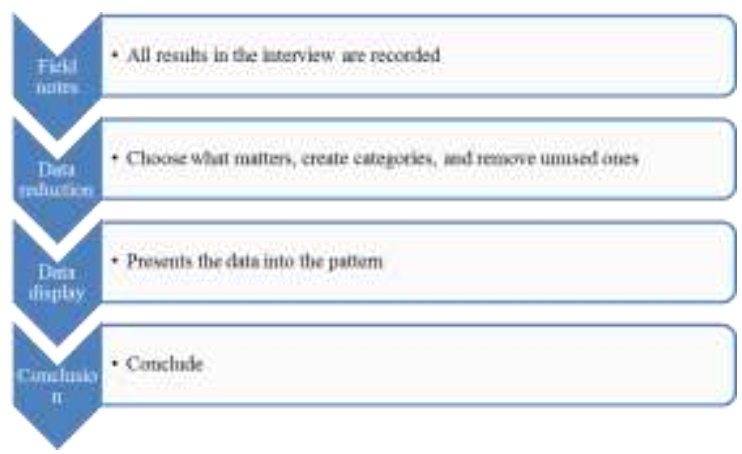

Source : Adapted from John W. Creswell (2014) and modified in accordance with this study

\section{Findings and Discussions}

\subsection{Student's awareness to go to school} Indonesia National Education System is regulated in Article 34 paragraph (4) of Law Number 20 Year 2003. Especially for the implementation of compulsory education program is regulated in the Government Regulation of the Republic of Indonesia Number 47 Year
2008. Compulsory education is a minimal education program to be followed by Indonesian citizens on the responsibilities of the Government and local governments. This Regulation on Compulsory Learning shows the government's commitment in the education sector. The central government and local governments ensure the implementation of compulsory education programs at least in elementary education without cost. The implementation of compulsory basic education program is part of education policy in Indonesia in achieving education for all.

Article 9 paragraph (1) to paragraph (4) in the Government Regulation of the Republic of Indonesia Number 47 Year 2008 on Compulsory Education, explains that children aged 7 to 15 years (9 years) are guaranteed to follow compulsory education. This article also explains the exemption of tuition fees in compulsory education programs is for children whose parents / guardians are not able to finance education. In Indonesia, 7 to 15 years of age must undertake formal education in primary school (including equivalent) for 6 years and Junior High School (including equivalent) for 3 years. Compulsory study serves to strive for expansion and equality of opportunities to obtain quality education for every Indonesian citizen and compulsory learning aims to provide minimal education for Indonesian citizens to be able to develop their potential to be able to live independently in the community or continue education to a higher level. This regulation becomes an aspect to increase the level of awareness to go to school. According to Irwanto (2010) that the participation of students and students with disability is strengthened by the enactment of policies on the implementation of inclusive education.

WI1 says that: 
"Elementary school age in Indonesia is 7 to 15 years. The average Indonesia has a 9 year basic education participation of $92 \%$. Indication of $8 \%$ who are not attending school because: 1) in remote areas, 2) have special needs, 3) experiencing natural disasters, 4) experiencing special violence. The number of crew in Indonesia is more than 1.6 million people. Based on interviews with the Ministry of Education there are only 360 thousand handled. The cause of small participation is also due to the role of shy and hiding parents if their children have special needs."

WI3 commented that:

"Awareness of parents to send their children who have special needs is getting better. But the condition is still limited in urban areas. This is because the facilities in the city have started to support to hold special education. Some parents are also not ashamed to bring their children with special needs to public places. In contrast, the participatory level of schooling for children with special needs is still low."

ABK participatory levels can be seen from School Participation Figures (APS), Special Participation Rate (APK), and Net Enrollment Rate (APM). School Participation Rate (APS) is the proportion of all school-aged children in a certain age group of people with appropriate age groups ${ }^{1}$. Special Participation Rate (APK) is the proportion of school children at a certain level to the population in a specific age group ${ }^{1}$. High APKs indicate high levels of school enrollment, regardless of the age of school at the level of education. If the value of APK is close to or more than 100 percent indicates that there are residents whose schooling is not sufficient for age and / or over the required age. It can also show that the region is able to accommodate school-age residents more than the real target. Net Enrollment Rate (APM) is the proportion of population in certain age groups of education who are still attending the population of that age group3. APM shows how many school-age residents who have been able to utilize educational facilities in accordance with the level of education. If APM $=100$, then all school-aged children can attend school on time.

Table 1. Percentage of APS, APK and APM Indonesia Year 2015

\begin{tabular}{|c|c|c|c|}
\hline $\mathrm{NO}$ & & Category & $\begin{array}{l}\text { Percentage } \\
(\%)\end{array}$ \\
\hline \multirow[t]{4}{*}{1} & \multirow[t]{4}{*}{ APS } & $\begin{array}{l}7-12 \text { years } \\
\text { old }\end{array}$ & 99.09 \\
\hline & & $\begin{array}{l}13-15 \text { years } \\
\text { old }\end{array}$ & 94.72 \\
\hline & & $\begin{array}{l}16-18 \text { years } \\
\text { old }\end{array}$ & 70.61 \\
\hline & & $\begin{array}{l}19-24 \text { years } \\
\text { old }\end{array}$ & 22.95 \\
\hline \multirow[t]{3}{*}{2} & \multirow[t]{3}{*}{ APK } & $\begin{array}{l}\text { Elementary } \\
\text { School }\end{array}$ & 110.50 \\
\hline & & $\begin{array}{ll}\text { Junior } & \text { High } \\
\text { School } & \end{array}$ & 91.17 \\
\hline & & $\begin{array}{l}\text { Senior High } \\
\text { School }\end{array}$ & 78.02 \\
\hline \multirow[t]{3}{*}{3} & \multirow[t]{3}{*}{ APM } & $\begin{array}{l}\text { Elementary } \\
\text { School }\end{array}$ & 96.70 \\
\hline & & $\begin{array}{l}\text { Junior High } \\
\text { School }\end{array}$ & 77.82 \\
\hline & & $\begin{array}{ll}\text { Senior } & \text { High } \\
\text { School } & \\
\end{array}$ & 59.71 \\
\hline
\end{tabular}

Source : https://data.go.id

\subsection{Grouping of students with special needs in special and general schools}

WI1 commented that:

"Special School (SLB) is a school that really handles schools with children with special needs ... If the 
inclusive is actually in the mainstream, children with special needs in public schools."

WI2 gives answer that

"Inclusive schools in
Indonesia only existed in the
2000 s, and differed from
SLB. If in the SLB when those
who are visually impaired
are in the blind class, those
who are deaf are in the
hearing-impaired class."

WI3 gives answer that

"SLB grouping depends, if in big cities like Bandung, Jakarta and Surabaya, the grouping is good. Such as $S L B$ A for the blind and SLB $B$ for the Deaf."

The division of SLB based on its kindness can be grouped into 5 (five) namely SLB A, SLB B, SLB C, SLB D, and SLB E. SLB A handles students with visual impairment, SLB B handles deaf students, SLB C handles mentally disabled students, SLB D handles physically handicap students and SLB E handle emotionally retarded students. Then specifically for autism students grouped again into the group SLB F. But for the case of SDLB, SMPLB, SMALB in it consists of several disability. As for the inclusive school is a public school that serves children with special needs. in some cases SLB C seems to be varied there are students with disabilities and Down syndrome. Grouping of children with special needs that have been good in big cities like Bandung, Jakarta and Surabaya. While in some other areas are still constrained by the limited number of schools, classrooms and teaching staff.
Public schools will provide the environment to $\mathrm{ABK}$ to get along with normal children. This can be a place to practice and socialize in the community. When attending regular school, ABK shows good behavior.

Difference between $\mathrm{ABK}$ at private and public inclusive schools. Private inclusive schools (eg Mutiara Bunda, Sembilan Mutiara and Gagas Ceria) schools with high school fees can provide inclusive education well. Start from facilities, teachers and services. In this private school the capacity of $\mathrm{ABK}$ is limited to only 2-3 children with 4 teachers with the composition of classroom teachers, special escort teachers, orthopedagogic teachers, and teacher assistants as teaching staff. But the problem is that the expensive cost must be borne by parents / guardians of students. A good private inclusive school fees of over 20 million rupiah and Education Contribution (SPP) fee above 2 million rupiah per month. Contrary to the public inclusive school, at the Elementary School level, one class can have a ratio of 60: 40, 60 for $A B K$ and 40 for normal students.

\subsection{Distribution of Special Schools in Indonesia}

All WI said the same thing for the spread of special schools in Indonesia has not been evenly distributed. According to the regulation in Indonesia (Permendiknas No. 70 Year 2009), the obligation of the implementation of inclusive schools is only for the urban level. In each urban district is required to have 1 inclusive school at the elementary and junior high school levels. While for high school is required for the province. While at the rural level, inclusive education is organized non-formally by the community. The spread of inclusive schools is concentrated on the Java Island, while for outer islands there is no guarantee that 
districts have 1 inclusive school at elementary and junior high school levels.

Based on special school statistics which published by the Ministry of Education and Culture in 2017, in general, Indonesia has 2070 special schools: 545 public schools and 1,525 private schools. Special schools are concentrated on the Java Island with a percentage of over than $60 \%$.

\subsection{Supporting educational facilities and infrastructure in special and inclusive schools}

Education Indonesia has 8 National Standards of Education consisting of 1) graduate competency standards, 2) content standards, 3) process standards, 4) education and educator standards, 5) standards of facilities and infrastructure, 6) management standards, 7) education financing standards, and 8) educational assessment standards. Regulations on Facilities and infrastructure in special and inclusive schools are regulated in Government Regulation No. 33/2008 concerning Standards of Facilities and Infrastructure for SDLB, SMPLB and SMALB. In that regulation described minimum feasibility standards for special schools there are land, buildings, and completeness of facilities and infrastructure. Periodically accreditation is made for each school; the accredited school must meet the minimum eligibility standards.

In terms of number and class conditions, data from the Ministry of Education and Culture in 2017, the number of classrooms provided 19,727 classrooms. But not all classes are in good condition. Of the total number of classes available, only about $35 \%$ are in good condition. Here are the details of class conditions: in good condition as many as 7,017 classes, in lightly damaged condition as many as 11,032 classes, in moderate damage condition as many as 718 classes, in

Cite this as:

Ediyanto, Atika, Iva nadya, Kawai, Norimune,, Prabowo, Edy. Inclusive Education In Indonesia From The Perspective Of Widyaiswara In Centre For Development And Empowerment Of Teachers And Education Personnel Of Kindergartens And Special Education Indonesian Journal of Disability Studies (IJDS). 2017: Vol. 04 (02): 104-116.

heavily damaged condition as many as 524 classes and in total damaged condition as many as 436 classes. Complete can be seen in table 2.

Table 2. Number and condition of classes at Special Schools 2016/2017

\begin{tabular}{lllll}
\hline No & Condition & Public & Private & Total \\
\hline 1 & Good & 2,753 & 4,264 & 7,017 \\
\hline 2 & $\begin{array}{l}\text { Light } \\
\text { damaged }\end{array}$ & 4,021 & 7,011 & 11,032 \\
\hline 3 & $\begin{array}{l}\text { Medium } \\
\text { damaged }\end{array}$ & 265 & 453 & 718 \\
\hline 4 & $\begin{array}{l}\text { Heavy } \\
\text { damaged }\end{array}$ & 146 & 378 & 524 \\
\hline 5 & $\begin{array}{l}\text { Totally } \\
\text { damaged }\end{array}$ & 158 & 278 & 436 \\
\hline & Total & 7,343 & 12,384 & 19,727 \\
\hline Source:
\end{tabular}

Source: Ministry of Education and Culture data 2017 in SLB statistics 2016/2017

The standard of facilities and infrastructure of SDLB, SMPLB, and SMALB as stipulated in Government Regulation Number 33 Year 2008 regarding Standard of Facilities and Infrastructure for SDLB, SMPLB and SMALB is complete can be seen in table 3.

The school that runs the inclusive program, WI2 explains regularly getting help from the Directorate of PPKLK (Directorate of Special Education and Special Services Development) in the form of goods. Related to the utilization of such assistance, for SLB schools do not experience obstacles. But for inclusive schools, the provision of assistance usually does not match the needs of students' disabilities, as the provision of assistance to schools is the same. When compared with developed countries, Indonesia is still far behind. On the other hand, WI1 added 
that not all inclusive schools are ready to receive special needs children.

Public schools must meet national standards. Supporting facilities such as laboratories have not been optimized for children with special needs. Before the school became an inclusive school, the laboratory was built first. So, to do renovations have obstacles and improvements to the facilities of children with special needs are done periodically. While in SLB that is prepared for children with special needs, the school environment can be a learning laboratory. Almost all SLBs have laboratory facilities adapted to students' disabilities.

Facilities and infrastructure in both inclusive and special schools still use and adapt the development of existing technologies. Autistic students learn communication with special tools called PECS's communication systems. Blind students are provided with personal computers with braille and sound technology. For students with hearing impaired is provided personal computer or private phone with sign symbols. However, the use of such technology is still on the island of Java and Sumatra. Private schools that have strong financial backing have good media and technology for their students.

\section{Teacher in Special and Inclusive Schools}

Based on the special school statistics published by the Ministry of Education and Culture in 2017, in general, in the academic year 2016/2017, the number of admissions with special needs of 121,244 people with 47,399 students from public schools and 73,845 from private schools. The deployment of students is centered on the Java Island with a total of 69,214 students or the equivalent of $57 \%$ of the total students. The number is spread in 6 provinces with the distribution of Jakarta Capital Region as many as 5,610 students; 21,042 students of West Java province; Banten province 4,765 students; Central

Table 3. Infrastructure and Equipment Facilities SDLB, SMPLB, and SMALB

\begin{tabular}{|c|c|c|c|c|c|c|c|c|c|c|c|c|c|c|c|c|}
\hline \multirow[t]{2}{*}{ No } & \multirow{2}{*}{$\begin{array}{l}\text { Components of } \\
\text { Infrastructure }\end{array}$} & \multicolumn{5}{|c|}{ SDLB } & \multicolumn{5}{|c|}{ SMPLB } & \multicolumn{5}{|c|}{ SMALB } \\
\hline & & $\overline{\mathbf{A}}$ & B & $\mathbf{C}$ & D & $\mathbf{E}$ & A & B & $\mathbf{C}$ & D & $\mathbf{E}$ & A & B & $\mathbf{C}$ & D & $\mathbf{E}$ \\
\hline 1 & General Learning Rooms & $\mathrm{V}$ & $\mathrm{V}$ & $\mathrm{V}$ & $\mathrm{v}$ & $\mathrm{V}$ & $\mathrm{V}$ & $\mathrm{V}$ & $\mathrm{v}$ & $\mathrm{V}$ & $\mathrm{V}$ & $\mathrm{V}$ & $\mathrm{V}$ & $\mathrm{V}$ & $\mathrm{V}$ & $\mathrm{V}$ \\
\hline 1.1 & Classroom & $\mathrm{V}$ & $\mathrm{V}$ & $\mathrm{V}$ & $\mathrm{v}$ & $\mathrm{V}$ & $\mathrm{v}$ & $\mathrm{V}$ & $\mathrm{v}$ & $\mathrm{V}$ & $\mathrm{v}$ & $\mathrm{V}$ & $\mathrm{V}$ & $\mathrm{V}$ & $\mathrm{v}$ & $\mathrm{v}$ \\
\hline 1.2 & Library* & & & & & & & & & & & & & & & \\
\hline 2 & Special Learning Space & & & & & & & & & & & & & & & \\
\hline 2.1 & Orientation and mobility room** & $\mathrm{v}$ & & & & & $\mathrm{v}$ & & & & & & & & & \\
\hline 2.2 & Development room & & & & & & & & & & & & & & & \\
\hline 2.2 .1 & Speech development room** & & $\mathrm{V}$ & & & & & $\mathrm{V}$ & & & & & & & & \\
\hline 2.2 .2 & Perception and rhythm room** & & $\mathrm{V}$ & & & & & $\mathrm{V}$ & & & & & & & & \\
\hline 2.3 & Self-development room $* *$ & & & $\mathrm{~V}$ & & & & & $\mathrm{v}$ & & & & & & & \\
\hline 2.4 & Self-development and activity room** & & & & $\mathrm{v}$ & & & & & $\mathrm{V}$ & & & & & & \\
\hline 2.5 & Personal and social building room** & & & & & $\mathrm{V}$ & & & & & $\mathrm{v}$ & & & & & \\
\hline 2.6 & Skill room* & & & & & & $\mathrm{v}$ & $\mathrm{V}$ & $\mathrm{V}$ & $\mathrm{v}$ & $\mathrm{V}$ & $\mathrm{V}$ & $\mathrm{V}$ & $\mathrm{v}$ & $\mathrm{v}$ & $\mathrm{V}$ \\
\hline 3 & Supporting Room & & & & & & & & & & & & & & & \\
\hline 3.1 & Lead room* & $\mathrm{V}$ & $\mathrm{V}$ & $\mathrm{V}$ & $\mathrm{v}$ & $\mathrm{V}$ & $\mathrm{v}$ & $\mathrm{V}$ & $\mathrm{v}$ & $\mathrm{v}$ & $\mathrm{v}$ & $\mathrm{v}$ & $\mathrm{v}$ & $\mathrm{v}$ & $\mathrm{v}$ & $\mathrm{V}$ \\
\hline 3.2 & Teacher's room* & $\mathrm{V}$ & $\mathrm{V}$ & $\mathrm{v}$ & $\mathrm{v}$ & $\mathrm{V}$ & $\mathrm{v}$ & $\mathrm{V}$ & $\mathrm{v}$ & $\mathrm{v}$ & $\mathrm{v}$ & $\mathrm{V}$ & $\mathrm{V}$ & $\mathrm{v}$ & $\mathrm{v}$ & $\mathrm{v}$ \\
\hline 3.3 & Administration room* & $\mathrm{V}$ & $\mathrm{v}$ & $\mathrm{V}$ & $\mathrm{V}$ & $\mathrm{V}$ & $\mathrm{v}$ & $\mathrm{V}$ & $\mathrm{V}$ & $\mathrm{V}$ & $\mathrm{v}$ & $\mathrm{V}$ & $\mathrm{V}$ & $\mathrm{V}$ & $\mathrm{V}$ & $\mathrm{V}$ \\
\hline 3.4 & Pray room* & $\mathrm{V}$ & $\mathrm{v}$ & $\mathrm{V}$ & $\mathrm{V}$ & $\mathrm{V}$ & $\mathrm{V}$ & $\mathrm{V}$ & $\mathrm{V}$ & $\mathrm{V}$ & $\mathrm{V}$ & $\mathrm{V}$ & $\mathrm{V}$ & $\mathrm{V}$ & $\mathrm{V}$ & $\mathrm{V}$ \\
\hline 3.5 & Medical room* & $\mathrm{V}$ & $\mathrm{v}$ & $\mathrm{V}$ & $\mathrm{V}$ & $\mathrm{V}$ & $\mathrm{v}$ & $\mathrm{V}$ & $\mathrm{V}$ & $\mathrm{V}$ & $\mathrm{V}$ & $\mathrm{V}$ & $\mathrm{V}$ & $\mathrm{V}$ & $\mathrm{v}$ & $\mathrm{V}$ \\
\hline 3.6 & Counseling room* & $\mathrm{V}$ & $\mathrm{v}$ & $\mathrm{V}$ & $\mathrm{V}$ & $\mathrm{V}$ & $\mathrm{v}$ & $\mathrm{V}$ & $\mathrm{V}$ & $\mathrm{V}$ & $\mathrm{V}$ & $\mathrm{V}$ & $\mathrm{V}$ & $\mathrm{V}$ & $\mathrm{v}$ & $\mathrm{V}$ \\
\hline 3.7 & Student organization room* & & & & & & $\mathrm{V}$ & $\mathrm{V}$ & $\mathrm{V}$ & $\mathrm{V}$ & $\mathrm{V}$ & $\mathrm{V}$ & $\mathrm{V}$ & $\mathrm{V}$ & $\mathrm{V}$ & $\mathrm{V}$ \\
\hline 3.8 & Toilet* & $\mathrm{V}$ & $\mathrm{v}$ & $\mathrm{V}$ & $\mathrm{v}$ & $\mathrm{V}$ & $\mathrm{v}$ & $\mathrm{V}$ & $\mathrm{v}$ & $\mathrm{V}$ & $\mathrm{v}$ & $\mathrm{V}$ & $\mathrm{V}$ & $\mathrm{V}$ & $\mathrm{V}$ & $\mathrm{V}$ \\
\hline 3.9 & Warehouse* & $\mathrm{V}$ & $\mathrm{v}$ & $\mathrm{V}$ & $\mathrm{V}$ & $\mathrm{V}$ & $\mathrm{V}$ & $\mathrm{V}$ & $\mathrm{V}$ & $\mathrm{V}$ & $\mathrm{V}$ & $\mathrm{V}$ & $\mathrm{V}$ & $\mathrm{V}$ & $\mathrm{V}$ & $\mathrm{V}$ \\
\hline
\end{tabular}




\begin{tabular}{|c|c|c|c|c|c|c|c|c|c|c|c|c|c|c|c|c|}
\hline 3.10 & Circulation space* & $\mathrm{V}$ & $\mathrm{V}$ & $\mathrm{V}$ & $\mathrm{V}$ & $\mathrm{V}$ & $\mathrm{V}$ & $\mathrm{V}$ & $\mathrm{V}$ & $\mathrm{V}$ & $\mathrm{V}$ & $\mathrm{V}$ & $\mathrm{V}$ & $\mathrm{V}$ & $\mathrm{V}$ & $\mathrm{V}$ \\
\hline 3.11 & Play area* & $\mathrm{V}$ & $\mathrm{V}$ & $\mathrm{V}$ & $\mathrm{V}$ & $\mathrm{V}$ & $\mathrm{v}$ & $\mathrm{V}$ & $\mathrm{V}$ & $\mathrm{V}$ & $\mathrm{v}$ & $\mathrm{V}$ & $\mathrm{V}$ & $\mathrm{V}$ & $\mathrm{V}$ & $\mathrm{v}$ \\
\hline
\end{tabular}

Information:

* One room can be used together for more than one type of disability and more than one level of education

** One room can be used together for more than one level of education

Source: Government Regulation Number 33 Year 2008 regarding Standard of Facilities and Infrastructure for SDLB, SMPLB and SMALB

Java province as many as 15,488 students; Yogyakarta Special Region 4,893 students and East Java province 17,416 students. Another data in the special school statistics published by the Ministry of Education and Culture of 2017, states that the number of teachers recorded as teachers in special education as many as 24,657 teachers with the division in public schools as many as 9,403 and 15,254 private schools teachers. When compared to total students, the ratio between teacher and student is as much as 1: 5 .

Ideally, number of teachers in the classroom is grouped according to students' level of disability. Students in the learning group who have mild disabilities, the ratio of teachers to students is 1: 10 . Students in study groups who have moderate fitness, the ratio of teachers to students is 1: 5 . And if students in study groups who have a severe level of fatness, then the ratio of teachers to students is $1: 1$ or 1:2. While the number of teachers on average in the classroom, the most ideal is there are at least 4 teachers in the class. Teachers in the inclusive classroom are classroom teacher, special assistant teacher, and orthopedagogic teacher.

In general, teachers who teach at SLB have not adapted to the type of student limitation. Teachers with backgrounds can be excellent teachers in school. The effort of PPPPTK Kindergarten and PLB as teacher trainers in the field of inclusive education is to provide training that is adapted to the field of teaching in school. Teachers in inclusive schools will be provided with special assistant teachers if there are children with special needs. One case described by WI1, Bali Province sent some teachers to PPPPTK Kindergarten and PLB to be trained on inclusive education. The teacher's background is from accounting, management, computer, science and others. After being trained by Widyaiswara, the teacher will be assigned or assigned to teach in public schools that serve children with special needs. Another case, delivered by WI2, teachers at SLB A has the deaf education background. In this case WI2 explained that, the teacher is given the burden of learning and attending the training became a teacher to blind students.

PPPPTK Kindergarten and PLB is a government office under the Ministry of Education and Culture whose job is to provide training to improve the quality of outstanding teachers. PPPPTK TK and PLB provide competency-based teacher training called Competence Based Training (CBT). Levels of training are start from primary level, middle level, advanced level and high level. The goal is all teachers or educators for children with special needs in schools throughout Indonesia. Teachers who become trainees are representatives of each province. This training is conducted periodically. While in certain areas such as Bali, Riau and East Kalimantan (areas where inclusive education campaigns) there was a type of cooperation with the central government in the form of provision of training and training bodies in the province.

\subsection{Learning Activities}


Inclusive schools are public schools that accept students with special needs. For inclusive schools, special needs children must follow national curriculum standards. Currently, the curriculum standard in Indonesia is the K13 curriculum. The curriculum refers to four components: process standards, content standards, assessment standards and graduation standards. The requirement is that students with special needs have no mental retardation or severe disability. If they have mental retardation, students do not take national examinations. As proof of students' graduation, the school issued graduation certificates that are not from the education office. Children with special needs who have taken the national exam and graduated are eligible to continue their education to a higher level. Meanwhile, special schools that are special schools for children with special needs, have a special curriculum tailored to students' disabilities.

The evaluation process in the inclusive school evaluation should be in accordance with the National Education Standards regulated in Government Regulation No. 32 of 2013. Evaluations are generally conducted with tests and non-complaints. The test can be done with objective tests and essays. Non-test evaluation can be through observation, peer assessment, self-assessment, portfolio or project assessment. $\mathrm{ABK}$ in inclusion schools are given the opportunity to get along with normal children in general. By interaction, $\mathrm{ABK}$ is also involved in all processes in socialization and communication. While in SLB, ABK are assessed based on Specific Lesson Program (PPI). The PPI is developed from the teacher's assessment of the classroom students. This aims to determine shortterm and long-term programs that are tailored to individual child development. Short-term programs, achievements can be measured in a one-semester evaluation. Long-term program, achievement can be

Cite this as:

Ediyanto, Atika, Iva nadya, Kawai, Norimune,, Prabowo, Edy. Inclusive Education In Indonesia From The Perspective Of Widyaiswara In Centre For Development And Empowerment Of Teachers And Education Personnel Of Kindergartens And Special Education Indonesian Journal of Disability Studies (IJDS). 2017: Vol. 04 (02): 104-116.

measured in the evaluation of one year of learning.

Measurement of academic achievement of ABK with normal children is different. Little ABK attainment is an achievement. For children with special needs, achievement in the form of selfimprovement is done step by step. Stages are applied to language skills, communication skills, social interaction and academic skills. A simple achievement, for example, calculations on learning, if the crew can know that shopping four thousand dollars while the money he had five thousand rupiah and return a thousand dollars, then this is a remarkable achievement.

\subsection{Children with special needs after graduation at a level of education}

Every student with a need is given a skill called self-development ability. Self-development is an exercise taught in school so that children with special needs can organize themselves and able to care for them independently in orders to behave just like normal children. In the activities of self-development students with special needs are taught to communicate and socialize (manners). Children with special needs are also provided with vocational or skill training. Vocations are developed specifically according to their abilities. Example in the community, blind children can be a masseur or a musician. It has been accepted in society. Upon graduation, education for crew who meet national standards can progress to a higher level. So it is possible that visually impaired people can pass a bachelor degree to a doctorate. At Universitas Pendidikan Indonesia, Prof. Didi Tarsidi is a blind. Prof. Didi Tarsidi has the advantage of recognizing a person from his voice and smoothly using a computer. The computer used has voice technology. Like a normal person, he is now a lecturer. 
For children with special needs who have mental retardation that is not ready to train and not ready to be educated will be forever. Not ready for educated means the child will remain in school. Not ready to train means that will always be trained self-development and skills to be able to do some things. Children with special needs like this have an attitude of dependence.

Exceptional schools or inclusive schools should further develop the potential and vocational abilities of children with special needs. The goal is that $\mathrm{ABK}$ can be more independent. For the vocational direction, schools can work with companies that can employ special needs children. Outside of the awareness is already there. In Singapore, there is a center for crew. Here, the potential of crew will be explored and then given training. Once skilled, the center is contacting the company to be able to employ special needs children who are skilled. While in Indonesia yet, there may be some companies that have realized and willing to serve $\mathrm{ABK}$.

In view of the legal and regulatory umbrella, Indonesia does not recognize discrimination. The 1997 Law on Disabled People states that it does not recognize discrimination for people with disabilities. So it is possible that a special ability will be accepted by all employment but adaptive. As in London, I accompany adults over 20 years to be accepted in the community. Autism can be accepted in the community with the job just to taste stamps at the post office. Then he can work in the library, he memorized all the books, he memorized all the books until the book codes, making book collection and placing the book. If in Indonesia, in general, we do not recognize discrimination, but not all areas can be entered by $A B K$. The teacher must be physically and mentally healthy, but there

Ediyanto, Atika, Iva nadya, Kawai, Norimune,, Prabowo, Edy. Inclusive Education In Indonesia From The Perspective Of Widyaiswara In Centre For Development And Empowerment Of Teachers And Education Personnel Of Kindergartens And Special Education Indonesian Journal of Disability Studies (IJDS). 2017: Vol. 04 (02): 104-116. are teachers who do not have hands but can teach.

PPPPTK TK and PLB provide special training for teachers to improve the quality of education under the auspices of the Ministry of Education and Culture. Meanwhile, related to skills training of children with special needs is handled directly by the Ministry of Social Affairs. Social Service trains people with disabilities to work. Gradually each year, the social services provide different skills training tailored to the talents of persons with disabilities. Examples of skill training that are implemented are painting training, sewing training, masseuse training and others. If the education in SLB, after the students graduate, there are no concern to empower the crew to be independent. But in Australia, we see something different, the school is very careful to be ready to work. After graduating school, the crew keeps to school and trained in skills like SMK. While PPPPTK its relationship with teachers who teach students. Out of the loose school is put into the foundation to be trained under the social service.

\subsection{Government efforts}

The government has a BOS program. So with the BOS program, schools no longer charge school fees from students at elementary and junior high schools. And now it is supported by the local government, being one of the targets to assist the BOS government. Based on that, in fact both state and private have been able to organize education in accordance with national standards. From the size of the GER in elementary school level already very well $110 \%$ they are in school. But in every province for APM there are about 2-3\% who do not finish school. Another government program is to use the Smart Card Indonesia program (KIP) to cope with them to go back to school. ABK is not only a disability, also a result of limitations in the economy, 
natural disasters and others. Government participation getting better and increasing. But based on the data, there are still crew who have not attended school, the obstacles 512 districts are only about 400 who have schools of inclusion. The government also often organizes seminars and training in PPPPTK. In the composition of the ministry of education programs, since 2 years ago there has started to be material about inclusive education and child protection.

Public awareness to enter school is getting higher. Schools still have obstacles to receive the crew because the problem does not have a special companion teacher (GPK), because has no facilities and infrastructure. What the government is doing communicates with local governments that do not yet have an inclusive school. Another reason is that access to the province is far enough. For inclusion schools, in addition to the boss funds are also given a grand block fund to improve the quality of crew services, improving facilities and infrastructure. Giving to the teacher special allowance to campaign to parents who have children with special needs to go to school. When there are children who are crew around the environment that has not been school, teachers are expected to persuade parents and their children let me go to school.

In the field of education, there has been no ministry of education for direct counseling to children. Government in the field of education approaches with socialization through educators. For example, the government calls for inclusive education in a region, the government invites teachers and schools to be given guidance on inclusive schools. Then the school device will visit the surrounding community to disseminate the existence of the inclusion school. Through school principals, school boards, graduate teachers and other school tools. As for the social service directly to the target.

Cite this as:

Ediyanto, Atika, Iva nadya, Kawai, Norimune,, Prabowo, Edy. Inclusive Education In Indonesia From The Perspective Of Widyaiswara In Centre For Development And Empowerment Of Teachers And Education Personnel Of Kindergartens And Special Education Indonesian Journal of Disability Studies (IJDS). 2017: Vol. 04 (02): 104-116.

\section{Conclusion}

School participation rate in Indonesia reaches $92 \%$. The reasons for not attending school are 1) being in remote areas, 2) having special needs, 3) experiencing natural disasters, and 4) experiencing violence. An inclusive school is a public school that accepts students with special needs. The curriculum used must comply with national education standards. the curriculum standard in Indonesia is the K13 curriculum However in the assessment, students with special needs have different assessment standards. Ideally, teachers in an inclusive class are at least four people consisting of one class teacher, two special escort teachers, and one orthopedagogic teacher. Facilities in inclusive schools should be tailored to students' disabilities. The commitment of the Indonesian government is to provide inclusive education as well as possible and periodically provide appropriate facilities.

\section{Further Direction}

1. There needs to be direct field research to find out the actual condition of the inclusive school.

2. It is necessary to measure the readiness and attitudes of teachers and students towards inclusive education.

3. Need more specific research on the meaning of inclusive education in Indonesia.

\section{References}

Ainscow, M. (2000). The next step for special education: Supporting the development of inclusive practices. British Journal of Special Education, 27, 76-80.

Creswell, John W. (2014). Research design: qualitative, quantitative and mixed 
methods approaches. United States: Sage Publication Ltd.

Hadis, Fawzia A. (2005). Toward inclusive, inclusive education in Indonesia a country report. Presented at Seisa University, Ashibetsu-shi Hokkaido Japan (July 9, 2005). Retrieved from http://www.jldd.jp/gtid/global_trend/6-

Toward_InclusiveInclusive_EducaIndonesia-Co.pdf.

Kwon, H. (2005). Inclusion in South Korea: The current situation and future directions. International Journal of Disability, Development and Education, 52(1), 59-68.

Media Indonesia. (2012, March). Jakarta: Pendidikan Inklusi di Indonesia Masih Lemah.

Meirina, Zita. (2015). Kemendikmud: angka partisipasi bersekolah anak berkebutuhan khusus rendah (Ministry of Education and Culture: the participation rate of children with special needs is low). Retrieved from http://www.antaranews.com/berita/527190 /kemdikbud-angka-pertisipasi-bersekolahanak-berkebutuhan-khusus-rendah.

Permendiknas No. 70, 2009 on Inclusive Education.
Poernomo, Baby. (2016). The implementation of inclusive education in Indonesia: current problems and challenges. American International Journal of Social Science Vol. 5, No. 3 pp. 144150 .

Rieser, Richard. (2012). Implementing inclusive education: a commonwealth guide to implementing article 24 of the UN convention on the rights of persons with disabilities. United Kingdom: Charlesworth Press.

Sunardi. 1995. Kecenderungan Dalam pendidikan Luar Biasa (Trends in Special Education). Dikti. Depdikbud. Jakarta.

UNESCO International Bureau of Education. (2009). Indonesia: national report on the provision of inclusive quality primary and junior secondary education for children with disabilities. Jakarta Office. Retrieved from http://www.ibe.unesco.org/fileadmin/user_ upload/Inclusive_Education/Reports/jakart a_09/indonesia_inclusion_09.pdf.

${ }^{1}$ (https://sirusa.bps.go.id/index.php?r=indi kator/view\&id=10)

${ }^{2}$ (https://sirusa.bps.go.id/index.php?r=indi kator/view\&id=8)

${ }^{3}$ (https://sirusa.bps.go.id/index.php?r=indi kator/view\&id=9) 